\title{
Improve Correspondence Learning Outcomes and Problem- Solving Capabilities by Developing Problem Based Learning Modules
}

\author{
Nisrina Fitriningtias' ${ }^{1}$, Madziatul Churiyah² \\ Department of Management, Universitas Negeri Malang \\ E-mail : nisrinafitri11@gmail.com
}

\begin{abstract}
This article aims to provide feasible Correspondence module based on Problem Based Learning model to improve problem solving ability and learning outcomes of learners in Vocational High School 1 Malang. The method uses the Dick \& Carey development model that has been modified by researchers. Data collection instruments used include structured interviews, questionnaires, tests, and documentation. Finding the result of the research, feasibility the subject module Correspondence Problem Based Learning achieved. In addition, there is also a significant difference between the average of control and experimental class problem solving abilities. Significant differences were also found in the mean of posttest learning outcomes between the experimental class and control class. The increase of pretest learning outcomes with control class posttest is significantly different from the average of pretest learning outcomes with experimental class posttest.
\end{abstract}

Keywords: Module, Problem Based Learning, Correspondence, Problem Solving Skill, Learning Outcomes.

\section{INTRODUCTION}

Human resources are an important key for the development of a nation, therefore it is necessary to make efforts to produce good and quality of human resources. An attempt that can be taken is by holding a good educational process that will have an impact on improving the quality of education at every level. In the other side, an effort to engage the quality of education is to make changes from the 2013 curriculum to the 2017 revised 2013 curriculum that fits the skills needed in the $21^{\text {st }}$ century that namely communication, collaboration, critical thinking, and problem-solving, and creativity and innovation. The 2017 revised 2013 curriculum contained the Higher Order of Thinking Skill (HOTS). Higher Order of Thinking Skills include critical thinking, logical thinking, and reasoning skills are basic skills for everyday life, regardless of academic achievement in school (Tajudin \& Chinnappan, 2016) and demand learning materials to metacognitive requirements that require participants students are able to predict, design, and estimate. Therefore, it is no longer possible to use teacher-centered learning models and methods, but lecturers/teachers need to activate students in active learning.

There are many learning methods that can be used by teachers in the learning process that are in accordance with the 2017 revised curriculum in 2017, one of which is a problem-based learning model. A problem-based learning model is a pedagogical approach that allows students to learn and actively participate in meaningful problems (Yew \& Goh, 2016: 75-76). 
Problem-based learning is a learning approach that presents contextual problems so as to stimulate students to learn (Yew and Goh, 2016). Problembased learning is problem-centered and students are centered on dynamic processes where students are actively involved in posing and solving problems related to the content and context being investigated (Major \& Mulvihill, 2017). In addition, the Problem Based Learning model which has learning objectives that can improve the ability to apply concepts to new or real problems and the integration of the HOTS concept. Moreover, in making a commercial letter, it takes the ability to solve a problem based on problems in the real world.

\section{METHOD}

This study uses the Dick \& Carey method which is often used in extensive research and development. In this model, it consists of ten stages. However, the researcher simplified a number of steps by not doing the $10^{\text {th }}$ stage (ten), namely the summative evaluation stage because the researcher did not measure the effectiveness of the module that the researcher developed and there was limited time in the field.

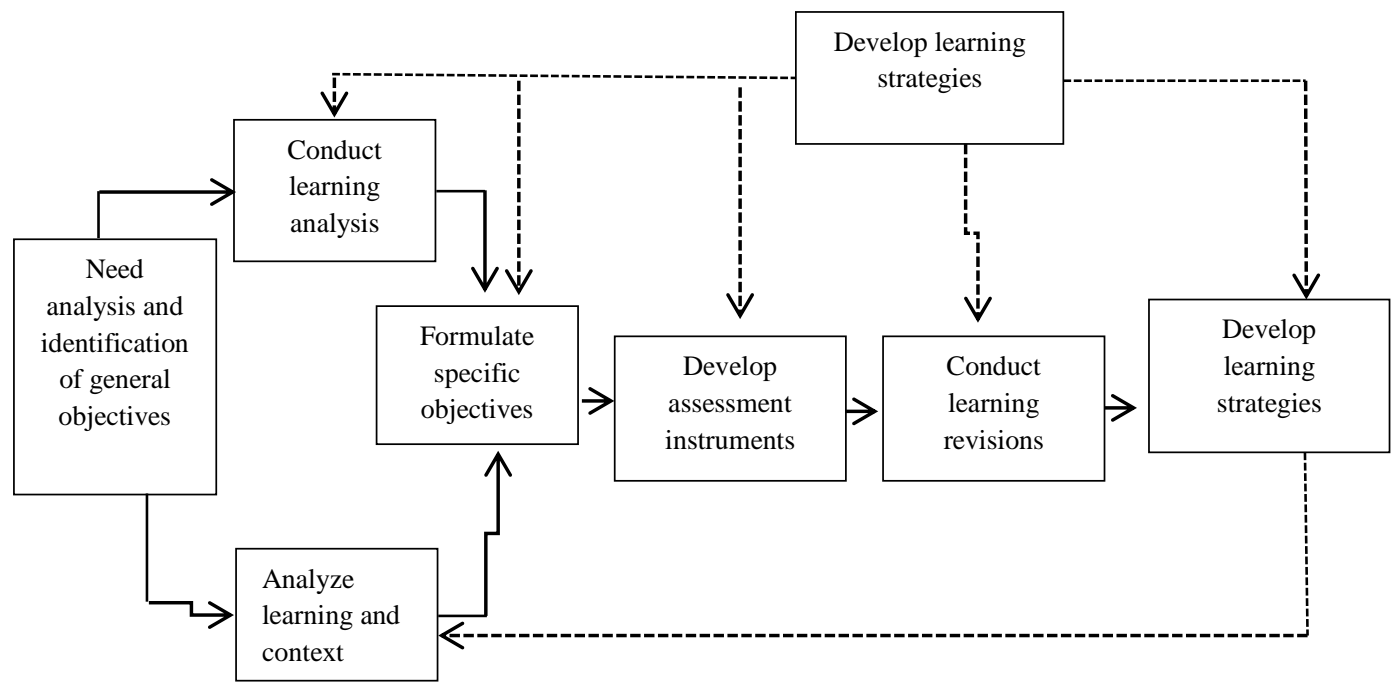

Figure 1. Method of Research and Development

This research was conducted in class $\mathrm{X}$ on the competency of Automation and Office Governance competencies at Vocational High School 1 Malang. The subjects of the small group trial consisted of 6 students apart from the experimental class and the control class. The large group field test subjects were divided into experimental classes 36 students and control classes 36 students. While product validation involves 2 validators, 1 material expert comes from subject teachers who master the material of correspondence at Vocational High School 1 Malang and have teaching experience of correspondence subjects for a minimum of 5 years and 1 expert learning module with S2-Technology Education qualification, Faculty of Education at Universitas Negeri Malang. 
Obtained from this development are qualitative-quantitative data. Qualitative data is obtained from notes, comments, criticisms, and suggestions provided by the validator that are used to improve the module and data on student activities. While quantitative data was obtained from the assessment questionnaire given to the trial subjects and initial tests with a scale of 5, pre-test and data from the post-test results. The data collected is data from the module expert test, material experts, small group trial subjects, and large group trial subjects.

\section{RESULTS \& DISCUSSION Results}

Development carried out by researchers is made in printed form, namely Problem Based Learning Correspondence Module which contains 6 (six) learning activities with 13 (thirteen) materials, namely trade letters, introductory letters, bid request letters, offer letters, order letters, order confirmation letters, order refusal letters, order delivery notification letters, payment delivery notification letters, complaints letters, complaints settlement letters, billing letters, and billing settlement letters.

This module was developed to support the learning and teaching process of classroom teaching, improve problem-solving skills, and improve learning outcomes in Class X Automation and Office Management expertise at Vocational High School 1 Malang based on the revised 2013 curriculum 2017. The correspondence module based on Problem Based Learning is one of the learning materials that applies the Problem Based Learning method as the work stage to understand the material and solve the cases and the problems in the module.

Table 1. Data on Module Validation Results by Module Experts

\begin{tabular}{|c|c|c|c|c|c|}
\hline \multirow[b]{2}{*}{ No. } & \multirow[b]{2}{*}{ Rated aspect } & \multicolumn{2}{|c|}{ Score } & \multirow[b]{2}{*}{ Percentage } & \multirow[b]{2}{*}{ Information } \\
\hline & & $\Gamma_{\mathrm{y}}$ & $\sum_{\mathrm{xi}}$ & & \\
\hline 1. & $\begin{array}{l}\text { Feasibility of } \\
\text { Presentation }\end{array}$ & 79 & 80 & $98.75 \%$ & $\begin{array}{l}\text { very valid/proper to be } \\
\text { used/able to be used }\end{array}$ \\
\hline 2. & $\begin{array}{l}\text { Feasibility of } \\
\text { Language }\end{array}$ & 64 & 65 & $98.46 \%$ & $\begin{array}{l}\text { Very valid/proper to be } \\
\text { used/able to bed used }\end{array}$ \\
\hline 3. & $\begin{array}{l}\text { Feasibility } \\
\text { graphic }\end{array}$ & 60 & 60 & $100 \%$ & $\begin{array}{l}\text { Very valid/proper to be } \\
\text { used/able to be used }\end{array}$ \\
\hline & Total & 203 & 205 & $99.02 \%$ & $\begin{array}{l}\text { Very valid/proper to be } \\
\text { used/able to be used }\end{array}$ \\
\hline
\end{tabular}

Data Source: Qualitative Data and Quantitative Data by Module Experts, 2018

The development of this module is based on a problem-based learning model with steps that consist of identifying problems, setting problems through thinking about problems and selecting relevant information, developing solutions through identifying alternatives, exchanging ideas and checking differences of views, doing strategic action, and review and evaluate the effects of the solutions made. The results of the validation questionnaire that 
have been filled in by module experts and material experts and the subjects of small group trials can be seen in Table 1.

Table 2. Data on Module Validation Results by Material Experts

\begin{tabular}{|c|c|c|c|c|c|}
\hline \multirow[b]{2}{*}{ No. } & \multirow[b]{2}{*}{ Rated aspect } & \multicolumn{2}{|c|}{ Score } & \multirow{2}{*}{$\begin{array}{c}\text { Percentage } \\
100 \%\end{array}$} & \multirow[b]{2}{*}{ Information } \\
\hline & & $\sum x$ & $\sum x i$ & & \\
\hline 1. & $\begin{array}{l}\text { Content } \\
\text { Feasibility }\end{array}$ & 68 & 70 & $97.14 \%$ & $\begin{array}{l}\text { very valid/proper } \\
\text { to be used/able to } \\
\text { be used }\end{array}$ \\
\hline 2. & $\begin{array}{l}\text { Feasibility of } \\
\text { Presentation }\end{array}$ & 76 & 80 & $95 \%$ & $\begin{array}{l}\text { Very valid/lproper } \\
\text { to be used/able to } \\
\text { be used }\end{array}$ \\
\hline \multicolumn{2}{|c|}{ Total Earnings } & 144 & 150 & $96 \%$ & $\begin{array}{l}\text { Very valid/proper } \\
\text { to be used/able to } \\
\text { be used }\end{array}$ \\
\hline \multicolumn{3}{|c|}{$\begin{array}{l}\text { Average Percentage of Total } \\
\text { Earnings from Module Experts, } \\
\text { Material Experts, and Trial } \\
\text { Subjects of Small Groups }\end{array}$} & & $97.51 \%$ & $\begin{array}{l}\text { Very valid/ proper } \\
\text { to be used/able to } \\
\text { be used }\end{array}$ \\
\hline
\end{tabular}

Data Source: Qualitative Data and Quantitative Data by Material Experts, 2018

Table 3. Data on Module Subject Test Trying A Small Group

\begin{tabular}{|c|c|c|c|c|c|}
\hline \multirow[b]{2}{*}{ No. } & \multirow[b]{2}{*}{ Rated aspect } & \multicolumn{2}{|c|}{ Score } & \multirow{2}{*}{$\begin{array}{c}\text { Percentage } \\
100 \%\end{array}$} & \multirow[b]{2}{*}{ Information } \\
\hline & & $\sum x$ & $\sum x$ & & \\
\hline 1. & $\begin{array}{l}\text { Content } \\
\text { Feasibility }\end{array}$ & 86 & 90 & $95.56 \%$ & $\begin{array}{l}\text { Very valid/ } \\
\text { lproper to be } \\
\text { used/able to be } \\
\text { used }\end{array}$ \\
\hline 2. & $\begin{array}{l}\text { Feasibility of } \\
\text { Presentation }\end{array}$ & 90 & 90 & $100 \%$ & $\begin{array}{l}\text { Very valid/ } \\
\text { lproper to be } \\
\text { used/able to be } \\
\text { used }\end{array}$ \\
\hline 3. & $\begin{array}{l}\text { Language } \\
\text { Feasibility }\end{array}$ & 60 & 60 & $100 \%$ & $\begin{array}{l}\text { Very valid/ } \\
\text { lproper to be } \\
\text { used/able to } \\
\text { be used }\end{array}$ \\
\hline 4. & $\begin{array}{l}\text { Feasibility } \\
\text { of graphic }\end{array}$ & 120 & 120 & $100 \%$ & $\begin{array}{l}\text { Very valid/ } \\
\text { lproper to be } \\
\text { used/able to } \\
\text { be used }\end{array}$ \\
\hline \multicolumn{2}{|c|}{ Total Earnings } & 356 & 360 & $98.89 \%$ & $\begin{array}{l}\text { Very valid/ } \\
\text { proper to be } \\
\text { used/ able to } \\
\text { be used }\end{array}$ \\
\hline
\end{tabular}

Data Source: Qualitative Data and Quantitative Data Small Group Trial Subjects,2018

Based on quantitative and qualitative data in Table 1, Table 2, and Table 3, it can be concluded that the Problem Based Learning correspondence module for class $\mathrm{X}$ students of Automation and Office 
Governance competency that has been created and developed by researchers is stated to be very valid so that it can be used or can be used in learning. The validators gave very good responses. In addition, based on the questionnaires distributed to the subjects of the small group of 6 students, the total acquisition was 98.89 percent. From these results, thus it can be stated that the Problem Based Learning based correspondence module for class X students of Automation and Office Governance competency competencies that have been created and developed by researchers for Malang State Vocational High School very valid/feasible to use/can be used in in the learning process.

The student's problem-solving abilities were assessed by four observers who were divided into two, each to assess the control class and the experimental class. The results of the assessment of the problem-solving abilities of each observer from the control class with the experimental class can be compared in Table 4 .

Table 4. Comparative Data on Problem Solving Ability between the Control and Experimental Classes

\begin{tabular}{|c|c|c|c|c|}
\hline \multirow[b]{2}{*}{ No. } & \multirow[b]{2}{*}{ Indicator } & \multicolumn{2}{|c|}{ Average Value Per Indicator } & \multirow{2}{*}{$\begin{array}{c}\text { Percentage of } \\
\text { Value } \\
\text { Difference }\end{array}$} \\
\hline & & Control Class & $\begin{array}{c}\text { Experiment } \\
\text { Class }\end{array}$ & \\
\hline 1. & Commication & $81.33 \%$ & $91.85 \%$ & $10.52 \%$ \\
\hline 2. & Planning & $78.63 \%$ & $92.58 \%$ & $13.95 \%$ \\
\hline 3. & Involvement & $78.75 \%$ & $99.72 \%$ & $20.97 \%$ \\
\hline 4. & $\begin{array}{l}\text { Information } \\
\text { Processing }\end{array}$ & $79.25 \%$ & $87.44 \%$ & $8.19 \%$ \\
\hline 5. & $\begin{array}{l}\text { Critical Analysis } \\
\text { Average }\end{array}$ & $\begin{array}{c}8.83 \% \\
79.96 \%\end{array}$ & $\begin{array}{l}91.54 \% \\
92.63 \%\end{array}$ & $\begin{array}{c}9.71 \% \\
12.67 \%\end{array}$ \\
\hline
\end{tabular}

Data Sources: Analysis of Critic Data Observation Results Ability to Solve Problem Control Classes and Experimental Classes (Appendix 6 a and attachment 9 a)

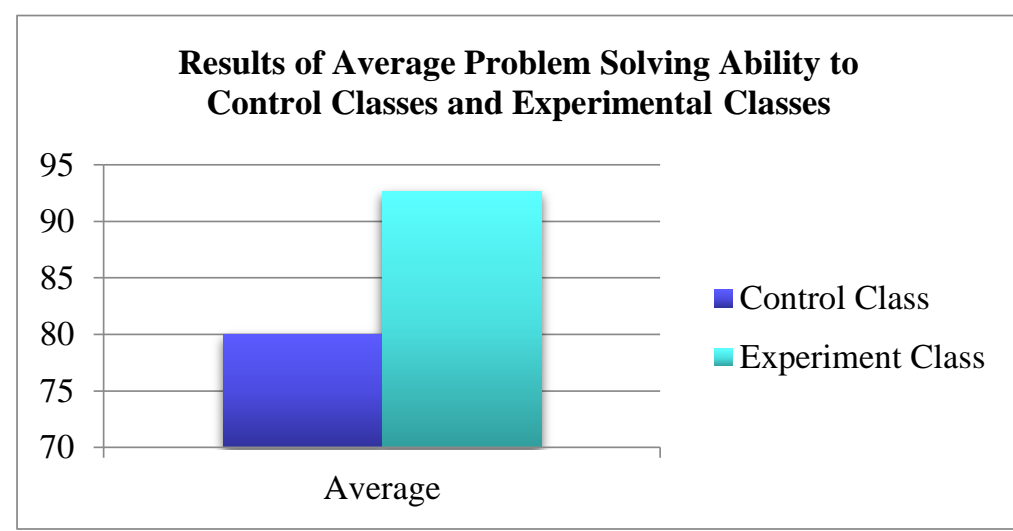

Figure 2. Results of Average Problem-Solving Ability to Control Classes and Experimental Classes

Based on Table 2, the average value of the observations of the problemsolving ability of the experimental class is 12.67 percent higher than the average value observed in the problem-solving ability of the control class. If 
seen in the diagram, the comparison of the results of the average problemsolving ability of students from the control class with the experimental class is shown in Figure 2.

Based on Table 1 and Figure 2, it is known that the average problemsolving ability of the experimental class is higher than the control class. The difference was caused by the experimental class using a Module based on Problem Based Learning while the control class did not use Problem Based Learning.

Whereas to measure the increase in learning outcomes of each control class, namely class X OTKP 1 and the experimental class namely X OTKP 3, the data were obtained from a comparison of the results of the average pretest values and the results of the average posttest scores. The control class data can be described in Table 5 .

Table 5. Comparison of the Average Results of the Pretest Value and the Posttest Value of the Control Class

\begin{tabular}{|c|c|c|c|c|}
\hline Aspects & $\begin{array}{c}\text { Score } \\
\text { average } \\
\text { Pretest } \\
(\%)\end{array}$ & $\begin{array}{l}\text { Score average } \\
\text { Post Test }(\%)\end{array}$ & $\begin{array}{c}\text { Percentage } \\
\text { Increase in } \\
\text { Learning } \\
\text { Outcomes } \\
(\%)\end{array}$ & Information \\
\hline \multirow{3}{*}{$\begin{array}{l}\text { Cognitive Aspect } \\
\text { Aspect } \\
\text { Psychomotor } \\
\text { Score }\end{array}$} & 45 & 61 & 16 & Increase \\
\hline & 73.81 & 83.33 & 9.52 & Increase \\
\hline & 59.41 & 72.17 & 12.76 & Increase \\
\hline \multicolumn{5}{|c|}{$\begin{array}{l}\text { Data Sources: Data on Pretest Learning Outcomes and Posttest of Control Class } \\
\text { Students }\end{array}$} \\
\hline \multicolumn{5}{|c|}{$\begin{array}{l}\text { Based on Table } 5 \text {, it can be seen that the percentage increase in } \\
\text { learning outcomes of the control class that does not use the Correspondence } \\
\text { Module based on Problem Based Learning is seen from the comparison of } \\
\text { pretest and posttest scores in the cognitive domain by } 16 \text { percent, in the } \\
\text { psychomotor domain at } 9.52 \text { percent, and the total percentage increase in } \\
\text { value by } 12.76 \text { percent. While the experimental class data can be described in } \\
\text { Table } 6 \text {. }\end{array}$} \\
\hline \multicolumn{5}{|c|}{$\begin{array}{l}\text { Table 6. Comparison of the Average Results of the Pretest Value and the } \\
\text { Posttest Value of the Experimental Class }\end{array}$} \\
\hline Aspects & $\begin{array}{c}\text { Score } \\
\text { average } \\
\text { Pretest } \\
(\%)\end{array}$ & $\begin{array}{l}\text { Score average } \\
\text { Post Test }(\%)\end{array}$ & $\begin{array}{c}\text { Percentage } \\
\text { Increase in } \\
\text { Learning } \\
\text { Outcomes } \\
(\%)\end{array}$ & Information \\
\hline $\begin{array}{l}\text { Cognitive } \\
\text { Aspect }\end{array}$ & 43.65 & 80.57 & 36.92 & Increase \\
\hline $\begin{array}{l}\text { Aspect } \\
\text { Psychomotor }\end{array}$ & 75.08 & 87.31 & 12.23 & Increase \\
\hline Score & 59.37 & 83.94 & 24.69 & Increase \\
\hline
\end{tabular}


Data Source: Data on Pretest Learning Results and Posttest of Experimental Class Students

Based on Table 6, it can be seen that the percentage increase in the learning outcomes of the experimental class using the Correspondence Module based on Problem Based Learning is seen from the comparison of the pretest and posttest scores in the cognitive domain by 39.92 percent, in the psychomotor domain 12.23 percent, and the total percentage increase in value of 24.69 percent. If depicted on a diagram, the comparison of the results of the average pretest and posttest values of the control class and experimental class can be seen in Figure 3

\section{Comparison of the Average Pretest Value and Posttest Value of the Control and Experimental Classes}

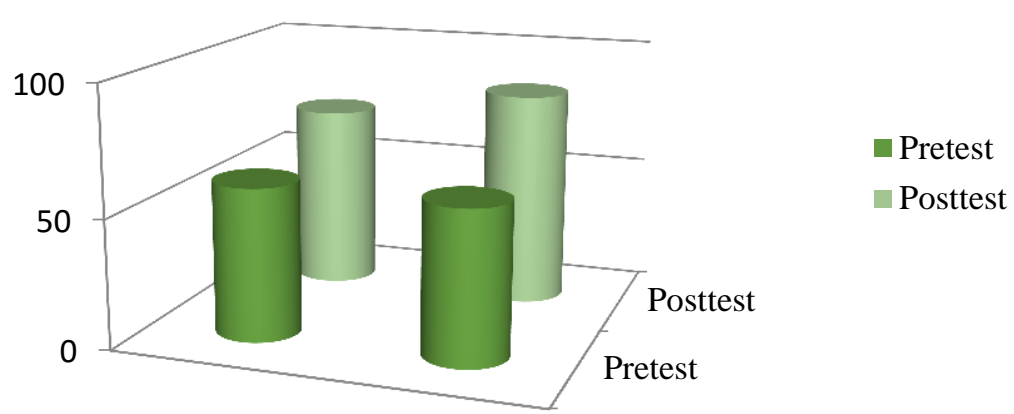

Figure 3. Comparison of the Average Pretest Value and Posttest Value of the Control and Experimental Classes

Based on Figure 3, it can also be seen that the percentage increase in the learning outcomes of the experimental class using the Correspondence Module based on Problem Based Learning is 11.93 percent higher than the control class that does not use the Correspondence Module based on Problem Based Learning. Therefore, it can be concluded that the Problem Based Learning-based Correspondence Module can also improve the learning outcomes of class X students in the skills competency in Automation and Office Management at Vocational High School 1 Malang.

Module development conducted by researchers is to produce a teaching material product in the form of a printed module, namely the Problem Based Learning correspondence module in KD. 3.8. Analyzing the Making of Commercial Letters and KD. 4.8. Making a Commercial Letter. The module developed has 6 learning activities to support the teaching and learning process in the classroom to improve learning outcomes in the cognitive and psychomotor domains and improve student's problem-solving abilities.

There are several advantages in the Correspondence module based on Problem Based Learning that researchers have developed. First, the module facilitates the learning process in Vocational High School 1 Malang, which 
does not yet have a revised 2013 curriculum-based Correspondence module 2017 because teaching books are one of the supporting factors in achieving learning objectives (Hanifah, 2014). Therefore, researchers develop and make correspondence modules based on Problem Based Learning as a support and facilitate the learning process to run effectively.

Second, in teaching does not prioritize the delivery of information, but also involves probing, discovering, analyzing, and directing (Karem, et al 2011). So that the existence of a module based on Problem Based Learning correspondence is very helpful in teaching because the main activity of the Problem Based Learning learning model is solving a problem starting from identifying problems to finding solutions based on those problems.

Third, the correspondence module based on Problem Based Learning that researchers develop using the stages of the Problem Based Learning model in learning modules. This is very helpful to create a learning atmosphere that is centered on students in learning because problem-based learning is one example of a learner-centered learning environment (Ylanne, et al 2003). Fourth, in the module Problem Based Learning based correspondence also contains evaluation questions with various commercial problem cases that can improve their psychomotor skills, namely the skill of writing a commercial letter based on an analysis of commercial mailing cases.

Fifth, in the module, there is a matter for the commercial letter that contains a case or problem regarding the commercial letter that must be solved. At each end of the learning activities in the problem-based correspondence-based module the researcher as the teacher also provides questions in the form of descriptions and to answer questions so that students can solve them directly.

Sixth, the module Correspondence based on Problem Based Learning can improve students' problem-solving abilities. Because, the purpose of the Problem Based Learning model includes helping students to develop flexible knowledge, effective problem-solving abilities, the ability to learn independently effectively, effective collaborative skills, and intrinsic motivation (Hmelo-Silver \& Eberbach, 2012). Seventh, the Problem Based Learning correspondence module can improve commercial letter writing skills because by studying the Problem Based Learning module correspondence students get metacognitive skills, including skills in analyzing problems, determining the strengths and weaknesses of students, strategies for solving problems and planning to examine progress and rearrange strategies (if necessary) and reflect approaches to learning (Gholami et al., 2016).

Lastly, the Problem Based Learning based correspondence module also facilitates students because it contains sufficiently complete material, uses easy-to-understand language, there are various examples of each sentence from the commercial letter, examples of each commercial letter, making a summary in the summary sheet which is available in modules and supporting images. Thus, students can apply learning styles visually and verbally. Learners visually very well remember what they saw, including 
many pictures, diagrams, graphs, timelines, films, and demonstrations (Pallapu, 2007).

In addition to the advantages contained in the correspondence module based on Problem Based Learning, there are also flaws in the Correspondence module based on Problem Based Learning, namely the first module Correspondence based on Problem Based Learning is only limited to KD. 3.8. Analyzing the Making of Commercial Letters and KD. 4.8. Making a Commercial Letter. This is due to the limited time provided.

Based on the results of observing the ability of problem-solving by 2 observers in the control class, aspects or criteria that the average value of the results of problem-solving abilities with the lowest average value is aspects or criteria of involvement. This is because students also do not use the Correspondence module based on Problem Based Learning that uses up to date problems so as to stimulate student motivation. Motivation can show whether students achieve learning goals or not, so better motivation will result in better learning success (Kurniawan, et al. 2017). Whereas the aspect or criteria that the average value of the results of problem-solving ability with the highest average value is the information processing criteria or aspects. This is because students do not use the Correspondence module based on Problem Based Learning as a source of learning. In fact, learning resources can be used as a source of activities that involve or offer students the opportunity to develop their competencies and abilities to be able to read, write and become independent students and effective end users (Busingnye \& Najjuma, 2015). Sed on observations of problem-solving abilities by two observers in the experimental class, the aspects or criteria that average the results of problem-solving abilities with the lowest average value are the information processing criteria or aspects. This is because experimental class students have provided Correspondence modules based on Problem Based Learning as the main learning resource so that they do not use a lot of material or other resources in working or completing assignments or commercial mail cases so that they are more focused and concentrated in learning.

Whereas the aspect or criteria that the average value of the results of problem-solving ability with the highest average value is aspects or criteria of involvement. This is due to the availability of using the Problem Based Learning correspondence module with various examples of sentences that are often used in making commercial letters, examples of trade letters, and the stages in completing a commercial letter case in accordance with the stages of the Problem Based Learning model. Motivating them to focus their attention on the task or case given and students actively participate in learning. A recent study stated that learners learn more when active learning is compared to traditional teaching methods, regardless of the subject matter. In addition, students tend to enjoy classes more and are able to store information longer (Shaaruddin \& Mohamad, 2017).

Based on the observation of problem-solving abilities by the observers, it is also known that the average value of the problem-solving ability of the control class is lower than the average value of the results of the 
experimental class's problem-solving abilities. This is because the control class does not have the main teaching material in the module to support learning. Modules that have proven validity are then tried out to control class students who do not use Problem Based Learning Correspondence modules with experimental classes using Correspondence based Problem Based Learning modules to determine the increase and difference in learning outcomes in the cognitive and psychomotor domains after based correspondence is applied Problem Based Learning. The learning outcomes are obtained from the value of the learning outcomes of the pretest and posttest.

Pretest can increase or decrease (depending on test characteristics) scores on posttest learning outcomes, not only for the same or similar scale but also for different scales where the constructs may be very different (Kim \& Wilson, 2010). Therefore, the researcher wanted to see whether there was an increase in the learning outcomes of the control and experimental class students seen from the average learning outcomes of the pretest and posttest.

Based on the learning outcomes of the pretest cognitive domain of control class and experimental class students it is known that the lowest average value of students is in the matter of analyzing commercial letters. This is because the analysis questions require high level thinking skills (HOTS) by finding errors and correcting errors presented in the matter of analyzing commercial letters. While the highest average score of students is in MCQs. This is because multiple choice questions make it easier for students to gain confidence in the ability to guess the correct answer or to find the desired response through the process of elimination, avoid tests that require good writing skills or are allowed to compensate for weaknesses in factual recall, and assume that tests using multiple choice questions are more objective (Bible et al., 2008).

The learning outcomes of the psychomotor domain pretest in the control class and experimental class students are known that the lowest average value of students at the time of completing the task is the case of the commercial letter. This is due to the limited time to solve the pretest questions and students are still shocked by the material that has not been studied before because the pretest includes the material to be taught and it is expected that students do not know beforehand (Berry, 2008). While the highest average score of students is in the aspects or criteria for work preparation. This is because the tools for making commercial letters have been prepared and the case letters of trade letters have been prepared by teachers and students. Preparation and organization in learning is one of the characteristics of effective teachers (Nasser \& Alhija, 2016). The existence of thorough preparation, makes students motivated to find out more about the material and the case of the commercial letter case, especially can improve the ability to think creatively and innovatively. In addition, students always attend on time as a form of their discipline. In addition, it is also known that the average value of the learning outcomes of the pretest control class is higher than the experimental class. 
After conducting research with large group trials using the Problem Based Learning Correspondence based module it was found that the cognitive posttest learning outcomes of control class and experimental class students, the lowest average value of students was in the trade letter analysis question, the same as the pretest. The issue of analyzing commercial letters in addition to demanding high-level thinking skills, the issue of commercial letters has a fairly high assessment weight compared to multiple choice questions and description questions. While the highest average score of students is in the problem description. This is because students during learning use a Problem Based Learning model that stimulates critical thinking skills and their problem solving. Essay questions or essay questions were praised for their ability to assess students' critical thinking skills, interpretations, and problem-solving skills (Wang et al., 2008).

The psychomotor domains of posttest learning outcomes in the control and experimental class students are known that the lowest average value of students at the time of completing the task is the case of the commercial letter. This is due to limited time to complete KD. 3.8. Analyzing the Making of Commercial Letters and 4.8. Making Commercial Letters is very limited at every meeting. This becomes a significant obstacle in learning. While the highest average value of students is in the aspect or criteria of the process (sitematics and work methods) by making and placing the completeness of the parts of the letter, using the language used in making appropriate introductory letters, there is the aesthetic writing of commercial letters on worksheets or books correctly and precisely in accordance with the knowledge and experience gained during the learning. Constructivism assumes that learning is a process of building knowledge rather than acquiring it. It takes the social, cultural and contextual conditions of students into consideration and theorizes that students build knowledge through experience (Guney \& Al, 2012).

After a large group trial, it was also known that the experimental class had a higher average value than the control class that did not use the Correspondence module based on Problem Based Learning. This is because the control class that does not use the correspondence module based on Problem Based Learning is tested for its feasibility and quality which is also equipped with complete material, examples of sentences often used in commercial letters, examples of each commercial letter, various questions containing cases of commercial letters that can be solved by the stages of the Problem Based Learning model, and learning media about KD. 3.8. Analyzing the Making of Selling and KD Letters. 4.8. Making Commercial Letters that can be accessed online. In addition, the average value of each pretest and posttest in the cognitive domain was lower than the psychomotor domain. This is reasonable because the thing that underlies motor activity is cognitive understanding (Coughlin \& Featherstone, 2017). Thus, learning outcomes in the psychomotor domain should be higher or equal to the learning outcomes in the cognitive domain because students before doing activities that exist in the psychomotor domain must first carry out activities that are in the cognitive domain. 
In addition, an increasing in the average value of the results of the pretest and posttest in the control class and experimental class, because the experimental class has used the correspondence module based on Problem Based Learning during learning. This is very influential because the control class only uses Slide PowerPoint media in learning. In fact, when textbooks (modules) and teacher guides are available for students and teachers, learning outcomes increase (Busingye \& Najjuma, 2015).

The results of the achievement of learning outcomes are found that the average value of completeness of the learning outcomes of students from the experimental class is higher than the control class. The incompleteness of the learning outcomes of the control class students is caused by not using the Correspondence module based on Problem Based Learning. In fact, one of the factors for a person to complete learning is one's effort to master teaching materials (modules) (Purwanto, 2011).

\section{CONCLUSION}

Results of the development in this study were in the form of Problem Based Learning Correspondence Modules for class X students of Automation and Office Management expertise Vocational High School 1 Malang. Based on the results of validation or due diligence by module experts, material experts, and small group trial subjects it is known that the Correspondence Module based on Problem Based Learning that has been created and developed has been highly validated or can be said to be very feasible to use. Problem Based Learning, there is a very significant difference between the control class that does not use Problem Based Learning based Correspondence Module and the experimental class that uses the Correspondence Module based on Problem Based Learning. Therefore,, it can be concluded that the Problem Based Learning based Correspondence Module that has been created and developed can improve the learning outcomes of the control and experimental class students seen from the value of the average learning outcomes of the pretest and posttest.

Suggestion for teachers to use the Correspondence Module based on Problem Based Learning in classroom learning activities and are advised to explore the material presented in the Correspondence module based on Problem Based Learning. Suggestions for students to use the Correspondence Module based on Problem Based Learning as the main learning source. In order to make the use of modules more effective, students can take part in all stages of the Problem Based Learning model presented in the module and complete all the questions contained in the Correspondence Module based on Problem Based Learning. 


\section{REFERENCES}

Berry, T. 2008., Pre-Test Assessment. American Journal of Business Education, 1(1), 19-22.

Bible, L., Simkin, M. G., \& Kuechler, W. L. 2008. Using Multiple-Choice Tests to Evaluate Students' Understanding of Accounting. Accounting Education: An International Journal, 17(0), 55-68. https://doi.org/10.1080/09639280802009249

Busingnye, J. D. \& Najjuma, R. 2015. Do Learning and Teaching Materials Influence Learning Outcomes Amidst High Enrolments? Lessons From Uganda's Universal Primary Education. Africa Education Review, 12(1), 109-126.

Coughlin, P. A., \& Featherstone, C. R. 2017. How to Write a High Quality Multiple Choice Question (MCQ): A Guide for Clinicians. European Journal of Vascular and Endovascular Surgery, 1-5. https://doi.org/10.1016/j.ejvs.2017.07.012

Gholami, M., Moghadam, P.K., Mohammadipoor, F., Tarahi, M.J., Sak, M., Toulabi, T., Pour, A.H.H. 2016. Comparing the effects of problembased learning and the traditional lecture method on critical thinking skills and metacognitive awareness in nursing students in a critical care nursing course. Nurse Education Today 45, 16-21. https://doi.org/10.1016/j.nedt.2016.06.007

Guney, A., \& Al, S. 2012. Effective Learning Environments in Relation to Different Learning Theories. Procedia - Social and Behavioral Science, 46(2012), 2334-2338.

Hanifah, U. 2014. The Importance of Quality Textbooks in Increasing the Effectiveness of Learning Arabic. Jurnal At-Tajdid, 3(1), 99-121. https://doi.org/10.1016/j.sbspro.2012.05.480

Hmelo-Silver, C. E., \& Eberbach, C. 2012. Learning Theories and ProblemBased Learning. Problem-Based Learning in Clinical Education. Innovation and Change in Professional Education, 8, 117. https://doi.org/10.1007/978-94-007-2515-7_1

Karem, A. F. H. A., Osman, K., \& Meerah, S. M. 2011. The Impact of Module Based Curriculum and Extra-Curriculum Activities' in Developing Environmental Skills among Saudi's Secondary Students. Procedia Social and Behavioral Sciences, 15(2011), 1756־1760.

Kim, S, E., \& Willson, L, V. 2010. Evaluating Pretest Effects in Pre-Post Studies. Educational and Psychological Measurement, 70(5), 744759.

Kurniawan, D.T., Suhandi, A., Kaniawati, I., \& Rusdiana, D. 2017. The Analysis of Learning Obstacleand Students Learning Motivation of Prospective Math Teachers in Basic Physics Class. Journal of Physics: Conference Series, 812(2017), 19. https://doi.org/10.1088/17426596/812/1/012026

Major, T. \& Mulvihill, T. M. 2017. Problem Bases-Learning Pedagogies in Teacher. Interdisciplinary Journal of Problem-Based Learning, 12(1), 111. https://doi.org/10.7771/1541-5015.1543 
Nasser, F. \& Alhija, A. 2016. Teaching in Higher Education: Good Teaching Through Students' Lens. Studies in Educational Evaluation, 54(2016), 19. https://doi.org/1016/j.stueduc.2016.10.006

Pallapu, P. 2007. Effects of Visual and Verbal Learning Styles on Learning. Institute for Learning Styles Journal, 1,3439.

Purwanto. 2011. Increased Motivation and Completeness of Learning Mathematics Through Cooperative Type STAD Learning at Ma'arif Wonosari Vocational School. Jurnal llmiah Guru "COPE", 2, 4557.

Shaaruddin, J., \& Mohamad, M. 2017. Identifying the Effectiveness of Active Learning Strategies and Benefits in Curriculum and Pedagogy Course for Undergraduate TESL Students. Scientific Research Publishing: Creative Education, Creative Education, 2017(8), 23122324. https://doi.org/10.4236/ce.2017.814158

Tajudin, N. M., \& Chinnappan. 2016. The Link between Higher Order Thinking Skills, Representation and Concepts in Enhancing TIMSS Tasks. International Journal of Instruction, 9(2), 199214.

Wang, S.-Y., Tsai, J.-C., Chiang, H.-C., Lai, C.-S., Lin, H.-J. 2008. Socrates, Problem-based Learning and Critical Thinking-A Philosophic Point of View. The Kaohsiung Journal of Medical Sciences 24, S6-S13. https://doi.org/10.1016/S1607-551X(08)70088-3

Yew, E.H.J., Goh, K. 2016. Problem-Based Learning: An Overview of its Process and Impact on Learning. Health Professions Education 2, 7579. https://doi.org/10.1016/j.hpe.2016.01.004

Ylanne, S, L., Pihlajamaki, H., \& Kotkas, T. 2003. What Makes a Student Group Successful? Student-Student and Student-Teacher Interaction in a Problem-Based Learning Environment. Learning Environments Research, 6(1), 5976. 